cemoti $\begin{aligned} & \text { Cahiers d'études sur la Méditerranée } \\ & \text { orientale et le monde turco-iranien }\end{aligned}$

$38 \mid 2006$

Islam au Caucase

\title{
L'Irak : de la constitution intérimaire a la constitution permanente
}

Halkawt HAKIM

\section{(2) OpenEdition \\ Journals}

Édition électronique

URL : http://journals.openedition.org/cemoti/1554

DOI : $10.4000 /$ cemoti. 1554

ISSN : $1777-5396$

Éditeur

AFEMOTI

Édition imprimée

Date de publication : 20 février 2006

ISSN : 0764-9878

Référence électronique

Halkawt HAKIM, «L'Irak: de la constitution intérimaire a la constitution permanente », Cahiers d'études sur la Méditerranée orientale et le monde turco-iranien [En ligne], 38 | 2006, mis en ligne le 13 février

2006, consulté le 08 septembre 2020. URL : http://journals.openedition.org/cemoti/1554; DOI :

https://doi.org/10.4000/cemoti.1554

Ce document a été généré automatiquement le 8 septembre 2020

Tous droits réservés 


\title{
L'Irak : de la constitution intérimaire a la constitution permanente
}

\author{
Halkawt HAKIM
}

\section{RÉSUMÉS}

L'élection du premier Parlement, le 15 décembre 2005, ouvre la voie à la mise en place de la «Constitution permanente» pour une période de quatre ans. Les vainqueurs, les chiites (128 sièges) et les Kurdes (59 sièges), affirment qu'aucun changement ne sera apporté à ses fondements et, surtout, au fédéralisme, une des "conditions" imposées par les Arabes sunnites pour qu'ils participent aux élections. Les chiites n'ont pas obtenu la majorité absolue qu'ils avaient obtenue dans le Parlement intérimaire, notamment à cause de la participation des Arabes sunnites qui boycottaient, jusque-là, toute sorte d'élections. Les engagements se multiplient pour affirmer que, cette fois-ci, tous les articles de la Constitution seront appliqués. Rien n'est moins sûr, surtout en ce qui concerne Kirkouk. 